THE THEORY AND PRACTICE OF S T A T U T ORY I N T ERPRETAT I O N 

F R A N K B C R O S S

\section{The Theory and Practice of Statutory Interpretation}

STA N F O D LA W B O O K

AN IMPRINT OF STANFORD UNIVERSITY PRESS

S T A NFORD, CALIF ORNIA 2009 
Stanford University Press

Stanford, California

(C) 2009 by the Board of Trustees of the Leland Stanford Junior University. All rights reserved.

No part of this book may be reproduced or transmitted in any form or by any means, electronic or mechanical, including photocopying and recording, or in any information storage or retrieval system without the prior written permission of Stanford University Press.

Printed in the United States of America on acid-free, archival-quality paper

Library of Congress Cataloging-in-Publication Data

Cross, Frank B.

The theory and practice of statutory interpretation / Frank B. Cross. p. $\mathrm{cm}$.

Includes bibliographical references and index.

ISBN 978-0-8047-59I 2-o (cloth : alk. paper)

I. Law-United States-Interpretation and construction. 2. Judicial process-United States. 3. Jurisprudence-United States. I. Title. $\mathrm{KF}_{42}{ }_{5} \cdot \mathrm{C}_{7} 62009$

$347 \cdot 73^{\prime}$ I $2-\mathrm{dc} 22$ 2008022514

Typeset by Westchester Book Group in IO/I4 Janson 